Migration Studies - Review of Polish Diaspora nr 2 (172)/2019, http://www.ejournals.eu/Studia-Migracyjne/

10.4467/25444972SMPP.19.015.10841

\title{
Mobility as a Strategy to Cope with Change: A Case Study of the Village of Wronka ${ }^{1}$
}

\author{
ALEKSANDRA TUROWSKA ${ }^{2}$ \\ Department of Ethnology and Cultural Anthropology \\ Adam Mickiewicz University Poznań
}

\begin{abstract}
Poland's accession to the EU exponentially increased the mobility of its citizens and changed the geography of Polish migration to Western Europe. Poles go abroad to improve their livelihoods: to work, earn competitive wages, and to study. Post-accession migrants hail mainly from small communities. The paper is based on empirical research in a small community of Wronka in the West Pomeranian Voivodship. The goal of this case study was to reconstruct the history of labour mobility of Wronka's residents, identify migration paths of their families, and analyse the effects of labour migration on the sending community. Departing from the customary analytical lens, this study analyses Polish mobility from the point of view of the sending, not the destination community. In the context of Wronka, mobility has become the norm in this previously immobile community centred around the state-owned farm, and appears to be a strategy used to cope with social, economic, and political change.
\end{abstract}

Keywords: labour migration, mobility, sending community, economic activity, transformation processes

\section{Introduction}

As a nation, Poles are used to emigration. Poles have always been on the move, going back and forth between nearby and far away countries (Baba and Dahl-Jørgensen 2010). Much of the scholarship on Polish migration in the enlarged European Union has focused on destination countries (Slany et al. 2008, Black et al. 2010, Baba and

\footnotetext{
1 The name of the town is fictitious to protect the identity of the inhabitants.

2Contact: ola.turowska@gmail.com
} 
Dahl-Jørgensen 2010, White 2011a, 2011b). Recently, the question about the social and cultural impact of migration within Europe on local communities - conceptualized as sending communities and points of return - has attracted the attention of some scholars (Grabowska and Engbersen 2016; White 2016; Grabowska 2016; Grabowska and Sarnowska 2017; Jaźwińska and Grabowska 2017). As a result of migration processes, local communities "have enlarged" and became transnational (Basch et al. 1994; Levitt 1998) or even translocal (White $2011 \mathrm{~b}$ ) spaces and channels of social remittances (Jaźwińska and Grabowska 2017: 140-141).

Social remittances or non-financial circulation and intermingling of old and new norms, values, and attitudes between origin and destination communities have always existed (see Levitt 1998; Orozco 2013; Grabowska and Engbersen 2016; Grabowska et al. 2017). At the turn of the $19^{\text {th }}$ century, scholars such as Znaniecki, Thomas, Chałasiński, and Krzywicki emphasized that migration produced more individualised lifestyles, which affected the inhabitants of sending communities. According to these scholars, migration not only promoted a new type of individual, more mobile and freer from the Polish feudal system and local social control, but also indirectly hastened the modernisation of isolated and remote rural areas of $19^{\text {th }}$ century Poland (comp. Grabowska and Engbersen 2016: 103). The present article aims to unpack Polish mobility from the point of view of the sending community and contribute to the debates on cultural impacts of migration on local communities in the European Union.

Polish mobility presents an excellent point of departure to analyse the role of migration and social capital in the context of social transformations that occurred after the fall of the Berlin Wall in 1989 and the expansion of the European Union in 2004 (Grabowska et al. 2017). Poland's accession to the EU exponentially increased the mobility of its citizens and changed the geography of Polish migration to Western Europe. Germany, for decades the main destination, was replaced by Great Britain. The vast majority -approximately 90 percent - of post-accession Polish labour migrants chose the United Kingdom. Following the financial crisis in Europe, Norway with its high wages and low unemployment has also become a popular destination (see Jaźwińska and Grabowska 2017; Main and Czerniejewska 2017). Moreover, post-accession migrants were much younger and better educated than Polish migrants before Poland's accession to the EU (Kaczmarek and Tyrowicz 2015). They hail mainly from small communities. Forty percent of Polish migrants to the UK come from mid-size and small towns of fewer than 100,000 inhabitants. An additional 33 percent come from villages. Only 28 percent come from cities of more than 100,000 residents (Grabowska-Lusińska and Okólski 2009). As White notes, social and economic changes in Poland, combined with social remittances from Western countries, may be contributing to a situation where 'rigid gender roles (father = breadwinner; mother = chief parent) will be eroded, at least partially' 
There is an urgent need to study Polish migration trajectories and processes from an anthropological perspective. Anthropology is a discipline that is particularly sensitive to place but comparative in its perspective. It allows migration scholars to focus on the articulation between the place where migrants originate and the place/s where they go (Brettell 2000) - temporarily or permanently - and explore how people in local places respond to global processes, acknowledging the role of individual agency in reproduction, reinvention, and resistance to new constellations of power formed through new forms of mobility.

The case study of Wronka was part of a larger ethnographic project, entitled "Mobile Lives, Immobile Realms: Female Mobility Between Poland and Norway," supported by the National Science Centre in Poland ${ }^{3}$. The project aimed at exploring social and cultural aspects of Polish migration to Norway, including increased feminization of migration between Poland and Norway, the role of Polish female migrants in the Norwegian labour market, migratory career paths, and the impact of female migration on children, families, and households in Poland and in Norway.

This paper ${ }^{4}$ is based on fieldwork conducted in Wronka by a group of fourteen researchers in May 2017. The goal of this particular case study was to reconstruct the mobility of Wronka's residents, identify migration paths of their families, and analyse the effects of migration on the sending community. In Wronka, mobility appears to be a strategy used to cope with political, economic, and social change. The paper includes several sections. I begin by presenting the historical antecedents of the case study of Wronka that led to the selection of this particular community for further exploration, followed by a discussion of the methodologies used to collect empirical data, and the theoretical frameworks within which the analysis of our findings has been performed. The bulk of the paper presents the views of Wronka residents on the effects the post-1989 transformation has had on the community and the ensuing mobility of its residents. The paper ends with some concluding remarks about the impact of mobility on small-scale communities in post-transitional Poland.

\section{The Study}

Serendipity played a role in the site selection: many of the Polish women we interviewed in Norway come from West Pomerania. We became curious about the effects their migration had on the families and communities they left behind. Therefore, we decided to take a closer look at the West Pomerania Voivodship and identify a local community for an in-depth case study. The process of site selection was very organic and took into consideration the following factors: a location away from large

\footnotetext{
${ }^{3}$ Grant number 2014/14/M/HS3/00842.

${ }^{4}$ I would like to thank Elżbieta M. Goździak for her comments and suggestions that helped me to write this paper.
} 
metropolitan agglomerations and industrial centres, and a community that included different institutions - e.g.; school, parish, mayoral office, and community centre - playing important roles in the local community. Wronka met all of these criteria.

\section{Methodological framework}

A methodological and empirical focus on local communities enables researchers to avoid easy generalizations affected by marred methodological nationalism (Wimmer and Glick Schiller 2002) and an overrepresentation of political history at the expense of social or economic perspectives (Pobłocki 2010: xii). As indicated above, the case study of Wronka constitutes a part of a larger research project involving multi-sited ethnography, a method of data collection that allowed us to follow a topic or social problem through different field sites in Norway (Oslo, Bergen, Kristiansund, Drammen) and in Poland (Poznań, Warsaw, Rzeszów, Gdańsk) and analytically explore transnational processes, people in motion, and ideas that extend over multiple locations (Marcus 1995). In the context of this study, the multi-sited ethnographic approach allowed us to focus on the "here," "there," and "in-between." Researching a given phenomenon from the perspective of the social field, whose boundaries do not have to coincide with the borders of a nation-state, enables researchers to distinguish how human agency and structure on the micro and meso levels are connected and transformed (Grabowska, et al. 2017: 7).

Prior to commencing the study of Wronka, we mapped the village and made a list of houses we wanted to visit. Based on the mapping exercise, we developed a "Household Sheet," a basic research tool for obtaining a local history of migration, in order to record the mobility of Wronka's residents: who migrated, when, and where they went. The questionnaire served as a starting point for further in-depth ethnographic interviews. The research team, composed of students and faculty of the Institute of Ethnology and Cultural Anthropology at the Adam Mickiewicz University in Poznan ${ }^{5}$ also engaged in observations of public spaces and events. Additionally, we also held meetings and talks with representatives of local elites: municipal councillors, members of the housing estate council, the parish priest, and the manager of the village centre. We visited 81 households and talked to over 100 residents. We heard stories of several dozen families whose migration journeys took them to 21 countries, including countries that no longer exist (USSR, DDR) or are not recognized internationally (Kosovo). The main destinations included: the United Kingdom, Germany and the Netherlands, however, Wronka residents also settled in Sweden, Denmark, Norway, Italy, France, Ireland, and Cyprus. A few respondents mentioned wanting to go the United States and Canada.

${ }^{5}$ Empirical research was conducted by Kajetan Baryła, dr Izabela Czerniejewska, Karolina Dziubata, Marta Jaszkowska, Zofia Lamprecht, Joanna Łopion, dr Izabella Main, Martyna Michałowska, Marcin Mielewczyk, Adrianna Regulska, Alexandra Staniewska, Karolina Sydow, Aleksandra Turowska and Grzegorz Walas. 


\section{Theoretical frameworks}

I have used several theoretical frameworks to analyse the empirical data. First, I have deployed the social anthropological critique (see Buchowski 2008, 2017) of the trauma of a great change theory (see Sztompka 2000, Winiecki 2001, Kocik 2001) . As $^{6}$ the empirical data show, people are not passive victims of system change, but active agents who shape the structural context in which they live. These individual practices contribute to a transformation of the totality of the social practice and the convictions which legitimize it (Buchowski 2017). As Grabowska indicates, after the fall of communism, people's qualifications lost their value and the level of wages was insufficient, but the system transformation resulted in open borders giving people the freedom to move. Thus, people started to manifest their agency in reproducing and creating new patterns of mobility (Grabowska 2016: 39). As Garapich (2016) indicates, individual actors are able to skilfully manoeuvre through diverse cultural and social environments in order to occupy privileged positions in both the sending and receiving society, resisting social and economic constraints in both.

Second, I use Elrick's understanding of migration culture after 1989. He argues that post-1989 migration played the same function in Polish local communities as state-owned factories and farms used to play in the previous era, especially in places that have already had a migration history and where incomplete migration patterns can still be observed (Elrick 2008). Working in state-owned farms was the norm in socialist Poland. Similarly, migration has become a norm in rural communities after transformation. This is particularly true in the case of short-term sojourns or seasonal migration (Grabowska and Engbersen 2016: 106).

It is worth emphasising that legacies of the communist period are now less important for social change and attitudes and that it is important to understand the substantial differences between the 1990s and the 2000s. Developments in international employment practices, combined with the rapid growth of international migration and transnational networks, are among the most significant factors shaping the lives of many citizens. This is not to deny that the roots of informality are endogenous,

${ }^{6}$ The concept of "trauma of a great change" was used by Polish political scientists, economists as well as by sociologists (see Sztompka 2000, Winiecki 2001, Kocik 2001) to specify the situation that took place in small communities in Poland after 1989. The sociologist Lucjan Kocik believes that the concept of trauma may revive and enrich qualitative sociological research of many social problems. The use of the "discourse of trauma" in the sociology of the village allows to draw attention to the painful realities of life of peasant families. "Definition of trauma," writes Kocik, "as a special kind of pathology of social subjectivity, opens a broad analytical and research perspective that explains many seemingly paradoxical phenomena. This perspective could be called an incapacitated and neutralized subjectivity with an activating and deepening trauma. An additional paradox includes the fact that agriculture is in a way 'genetically' predestined to subjectivity, which has never fully existed since prehistoric times. (...) The existence of agricultural production is a necessary condition for the existence of society, but society is not a necessary condition for the existence of farms. A good example of this is the situation of the fictional Robinson, who sustained the means of subsistence through 'a simple exchange with nature' (Kocik 2001: 21-22). 
in the sense that local migration networks pull in ever new inhabitants, while cultures of informality more generally can certainly be seen as historical legacies (White 2016). Thus, the third theoretical framework emerges from conceptualising mobility as an integral part of the broadly understood transformation process. This approach demands the recognition that an investigation of the migratory impact on sending and destination communities is limited by the fact that the social impact of migration is diluted by other processes and that complexity is increased by technological revolution (por. Grabowska and Engbersen 2016: 103).

The goal of this article is to show mobility and other agentic practices as strategies and cultural resources used to improve livelihoods. Empirical data showcasing perspectives of ordinary people indicate that different social groups experienced transformation in diverse ways (Buchowski 2017: 199). Empirical research also suggests that migration is often a deliberate decision to improve livelihoods, enable investments, and reduce fluctuations in family income that used to be largely dependent on climatic vagaries (de Haas 2010; White 2010, 2011a, 2016). Although livelihood strategies are usually studied in the context of international development, people everywhere deploy them, particularly in less well-off households. A livelihood is more than just going to work and earning money. It frequently spans a range of official and informal activities, such as additional earnings in the shadow economy and exchanging favours with neighbours (White 2016).

\section{The story of the town}

Wronka is located in Western Pomerania, a part of the territories annexed to Poland after WWII. The main housing estate has about 1,300 inhabitants and has four representatives in the commune council. Below I detail the establishment and development of various enterprises and institutions in Wronka as they are important parts of the community's identity. Their evolution and final dissolution have been crucial to the residents' livelihood strategies, including local and international mobility.

\section{The main enterprises and their transformations}

The period from the late 1940s to the mid-1950s was the time of proliferation of large state-owned and operated farms. Agricultural production in post-war Poland had its measurable effect in the form of establishing specialized agricultural research facilities. The Wronka Agricultural Research Institute, established in 1964, is an example of this trend. New facilities were built and the State Farm of Wronka became one of five experimental farms located in different regions of the country. The prestige of having a research institution in Wronka affected the identity of the town. While explaining the administrative complexities of the institutions in Wronka, our 


\section{SM̂PP}

interlocutors often stressed that the Wronka State Farm was not an ordinary state farm, but an experimental plant.

The Agricultural Research Institute attracted specialists and skilled agricultural workers from all over Poland. A vast majority of the housing estate residents were employees of the research enterprises. Thus, the local infrastructure catered to the research institutions and its employees. As one of the interviewees recalled:

I'm sure that we settled here because of housing. My husband got a job here and a flat, and we came here, just like everyone else. [Maria7, 60 years old].

Another interlocutor explained how she found herself in Wronka:

We were looking for a flat. I was living in a rooming house and my husband was looking for a place to live. He was from the city, but I wanted to live in a village. He wanted three rooms and I wanted two. So, the compromise was: three rooms in the countryside. And we stayed. [Katarzyna, 50 years old].

The 1970s were a period of intense development of the town centred around the research institution. Given the farmers' aspirations and expectations, housing and social welfare were the main priorities of state farms in the 1970s. When the housing estate, the club rooms and the community centre were built, the local "Ruch" club was also operating in the town. The village was active in the local chapter of ZSMP (Polish Socialist Youth Union), for years enjoying the title of the best ZSMP circle in the commune. In addition to the governing body, the enterprise also had its own party organization. The share of employees with secondary and higher education increased considerably in the 1960s and 1970s. The Agricultural Schools Centre was established in 1971, tasked with educating the agricultural cadres. In 40 years, 5,695 people graduated from the school; the largest number of students graduated in 1976-1979 and 1985-1986.

The end of the 1980s brought a preview of changes to come. In 1988, the institute employed about 120 people, however, just a year later the first reductions began. Restructuring followed: the institute and all of the experimental plants were incorporated into the National Breeding Research Institute. Centralization strongly affected the system of work organization and was remembered by employees as the symbolic end of a certain era. The emergence of foreign companies in Poland caused anxiety among the employees, uncertain what the competitive open market might bring. Ultimately, the institute has not been abolished and continues its research activities. However, despite the trade unions' attempts to stabilize employment, the 2000 s brought a wave of further redundancies. Some employees, including the management and staff, maintained continuity of employment, but the vast majority had to look for new opportunities. Academics who left the institute at the turn

7 The names of all interlocutors were changed to protect their identity. 
of the 1990s and 2000s were employed mainly at the Research Institute in Masovia and universities around the country.

Agricultural training and education continued in Wronka. In 2009, after ten years under the county executive, the Agricultural Education Centre was again incorporated into the structures of the Ministry of Agriculture and Rural Development. About 200 students pursue education as landscape architects, veterinary technicians, nutrition and gastronomic specialists, agricultural mechanics, and electricians at the technical high school. Additionally, two vocational schools train machinery operators and cooks. The schools also provide extramural education and operate a boarding house for out of county students. The school is struggling with the widespread tendency to depreciate vocational education in Poland. The tendency responds to the demands of the knowledge-based economy, where educated people were to be its pillars (see Sala and Tańska 2016). According to our interlocutors, the phrase "if you don't study, you will go to the agricultural school" expresses a kind of hierarchy of secondary schools where high schools enjoy prestige and vocational schools are treated second-rate players. Wronka used to have a small orphanage. Before its closure in the 1990s, the orphanage was also an important source of employment. As reported by the employees of the County Family Assistance Centre, the process of closing the facility was not easy. More than 50 children under the age of three were placed in foster care or adopted $^{8}$. Some people perceived it as an "anti-infant" strategy. The process required a wide-ranging information campaign and the transformation of existing beliefs regarding orphan care. Some of the criticism stemmed from a lack of understanding that foster families or group homes are indisputably a better place for children in need of care than large institutions. Some inhabitants saw the changes as part of a larger privatization processes: "They have closed because they have introduced these private homes. Everything is to be private today, no?"[Kazimierz, 70 years old].

\section{Housing, education, and cultural activities}

After the transformation, most of the employee flats were put on the market. The employees were able to buy these apartments at affordable prices, but this resulted in population rotation as the residents immediately sold their newly bought apartments to newcomers, who were attracted to Wronka because of its location close to a larger city but away from the highway, with easy access to parks and a good quality kindergarten and primary school. These features attracted young families with children. The former hotel, which belonged to the research institute, was also transformed into apartments for sale.

8 According to one of our interlocutors, whose wife worked in the orphanage for thirty years, some children were adopted by Swedish or Norwegian families. No documents on the orphanage were found during the fieldwork. 


\section{SM̂PP}

Despite the economic changes, Wronka has not lost population. In fact, in the past several years, the town has experienced an influx of residents from a nearby city and other towns; new residents have replaced "old" residents. The newcomers buy apartments from people who moved out of town or the inheritors of those who pssed away. One of our interlocutors came to Wronka with her family at the request of her sister who went to the Netherlands and left her apartment vacant. Before leaving, she managed to arrange for her brother-in-law to work at a local school. Another interlocutor moved to Wronka upon retirement and found an advertisement for a flat in the local newspaper.

In addition to the Agricultural Education Centre, there is also a primary school in Wronka with fewer than 150 pupils, as well as a municipal kindergarten. The housing estate is located on a bus route and children can access the school easily by public transportation. In the village, under the care of one of the residents, there is

a vibrant community centre, part of the County Cultural Centre, and a public library. The centre's talented manager conducts art classes for children. There are also fitness classes led by visiting instructors from the city. A women's group, founded by the owner of a local store, has been operating at the community centre for about ten years. The group organizes nationwide singing competitions. Since 2012, Wronka has also built a soccer field as a part of the government project "Orlik"

One of the themes emerging in our conversations with local residents was the influx of newcomers and their impact on the cohesion of the local community: older residents do not know newcomers and new ones do not try to integrate. Some of the new residents take their children to schools and kindergartens in the city on their way to work. Thus, Wronka has become a de facto bedroom community of the nearby city. At the same time, most of our interlocutors emphasized that Wronka is a nice place to live. Maria summed it up as follows:

I mean ... [people are leaving] out of necessity. For example, a married couple lives in a flat and then they have children. Sometimes they stay in a small apartment, sometimes someone dies, and sometimes someone just builds [a house], because he also lives in a small flat, and sometimes there are evictions. It happens. They do not pay their mortgage for four years and are in debt. It happens. But many people like me live here because there are a lot of parks, a lot of flowers, everything is nicely maintained. People are kind, because it seems to me that contact with nature gives peace. [Maria, 60 years old].

\section{Migration and mobility: the findings}

Wronka residents took advantage of the opportunity to travel after the fall of the Berlin Wall and Poland's subsequent accession to the EU. However, we have to bear

${ }_{9}$ Orlik is the name for soccer fields built in many municipalities in Poland before 2012, when Poland co-hosted the UEFA Cup, to promote sports among the youngest citizens. 
in mind that Wronka residents were mobile before the 1989 transformation and the 2004 accession to the EU. Many of our respondents used to go picking strawberries or to work on construction sites in Bonn when it was still the capital of West Germany. For some of them it was a way to improve their livelihoods after being laid off from the experimental plant. The daughter of one of our respondents, Karolina, met her future husband on a student practicum in Czechoslovakia. A few of our interlocutors have relatives in the United States. Mieczysław's brother left in the 1980s to join his wife's uncle, a member of the Home Army, who fled to the United States via Norway after WWII. The brother returned in 1988, "because he anticipated the 1989 transformation and noticed that things were loosening up and he came. He made good money there and built a house" [Mieczysław, about 70 years old].

Krystyna mentioned that her husband, Jerzy, worked in Magnitogorsk between 1989-1990 as part of a trip organized by the factory in wherein he worked. It was his second trip to the USSR; as a bachelor, he went on detail to Kaluga near Moscow. He volunteered because he saw this temporary transfer as an opportunity to buy a larger apartment for the family. Unfortunately, as a result of the collapse of the USSR and the devaluation of the Russian rouble, he did not make any money. In the end, Jerzy decided not to travel abroad anymore. It was also hard to endure being separated from the family. When the factory where he worked collapsed in the early 1990s, he was made redundant. Krystyna started her own cleaning business. She operated the business for over ten years but later found employment in human resources. Her husband found a job in a car windshield factory and has been working there ever since.

The case of Krystyna and Jerzy is an example of Okólski's concept of incomplete migration (see Okólski 2001, 2012; White 2011a). Incomplete migration strengthens conventional gender roles in the family, where women are responsible for raising children and men focus on earning money (Grabowska and Engbersen 2016: 106). The unforeseen turn of events, Jerzy being laid off, forced Krystyna to exercise entrepreneurial skills - starting her own business, earning money - she did not know she had. As a result, gender roles and family relationships changed.

The increased mobility of Wronka inhabitants occurred after the expansion of the EU in 2004. The vast majority of the residents experienced some sort of mobility, either directly or indirectly. Only two of the 81 families we visited never went anywhere. Among foreign destinations, the United Kingdom (29 trips) and Germany (24 trips) dominated; the Netherlands were also popular (13 trips). Some people tried their luck in various places and worked in two or three different countries. Wronka residents engaged in short-term, circular movements, which scholars term mobility (Goździak and Pawlak 2016: 109), and long-term migration. Most frequently people embarked on a foreign sojourn because their relatives or friends had migrated and enticed them to come. Some respondents mentioned using the services of recruitment agencies.

A few interviewees mentioned that joining a family member or a friend was 72 rarely a good idea as these relationships often ended in conflict. Conflict, difficult to 


\section{SM̂PP}

predict before leaving, resulted most often from misunderstandings and differences in expectations. One interlocutor explained it this way:

You are told to come because there is work. It happened to my partner, twice, he was going to join his brother. And later, when he came, he was told to look for work on his own. And then you know, grudges, accusations that he was just sitting at home and not looking for work. Well, but you know, he was at a loss, he didn't know where to go and what to do. [Beata, 30 years old]

\section{Mobility as strategy to cope with change}

According to our research, two beliefs about mobility prevail in the social consciousness of Wronka residents. On the one hand, mobility is seen as an opportunity, taking matters into one's own hands, resourcefulness. Being able to thrive abroad, finding a well-paid job, but above all leading an organized life are highly appreciated. Marzena respected the fact that her acquaintances work professionally:

[one daughter of a friend in Norway] works as a physiotherapist ... and the other, I am not quite sure what her job is, but they found work in their professions. [Marzena, 65 years old]

Barbara appreciated an entrepreneurship of her acquaintance:

She worked a little [in Germany] cleaning houses, and she also studied for two or three years. She works with diabetics, something to do with their feet. She also worked with another woman specializing in the same occupation. One day the lady said: "I am going to retire and if you want, I will rent you this office." And she agreed. She also sent her husband who was in the army for the same training. It is such a narrow specialization, these diabetic feet, nursing, dressing. She loved it. And those patients are grateful. It is not like here that the nurse comes once and is done. It's best to cut off your leg, no? There, she simply cares for these people and she does it beautifully. They go on holidays three times a year, travel around the world. [Barbara, 60 years old]

On the other hand, migration is also perceived as a necessary evil, an opportunity that one reaches for when other possibilities fail. Considering the scarcity of livelihood options for small-town residents without useful contacts, it is not surprising that migration is viewed as the "only" remaining possibility (White 2016). The interviewees often said that "people are leaving only out of necessity." When her daughter decided to leave the country to join her partner, Alina believed that "there is no need to travel abroad". Reportedly, someone else was forced to leave because he fell into debt. Urszula's story exemplifies the discourses surrounding transformation processes of the 1990s. The experiences of Urszula's friend confirm the prevailing neo-liberal belief that everyone is a master of their own destiny: 
A friend of mine left because she had a huge debt, about one million Polish zloty. She just went crazy, we worked together. She slowed down, rented property in a [beach resort] and simply wanted to be on her own. She read these motivational books. She said: "I take life into my own hands," but unfortunately, she encountered crooks who robbed her. She invested too much in the shop. She has not yet paid off her credit and had to pay twenty thousand for rent. And at some point, she decided to quit and leave for Germany. At the beginning, a friend of hers took her to Hamburg. She worked in a hotel for three German marks an hour. Later, another friend said: 'come, go to such and such place and start cleaning people's houses; there is a big demand'. She went there [to a village near Hamburg] and started working on her own, but after a while she said she didn't have insurance or a doctor or anything. After a year, she decided to set up a business: cleaning and caring for the elderly. Once she made a decision she got clients: offices and elderly ladies. At first, she rode her bike, now she is riding a beautiful car and her three children joined her. She paid off her debts in less than five years. [Urszula, 60 years old]

As Buchowski (2017: 209) asserts, these kinds of hegemonic discourses appeared in the public domain after 1989 and popularized neo-liberal views in the society. These views are quite firmly rooted in public opinions as evidenced by Beata's statement. Her partner and the majority of her family have worked abroad. She worked hard in a fish processing plant for very little money. Beata said:

I worked at a fish factory [in a nearby city]. I wanted to get pregnant, but did not want to sit at home without any money. It was exhausting, I cried every day, but I survived for half a year. There are ambitious and less ambitious people, I do not understand why they worked there. I guess they had their goals. I was terribly tired there, it wasn't worth it.

In the same conversation, Beata admitted:

It seems to me that there is work in Poland, but you have to want to work. And when someone complains that there is no work, that you have to go to the factory, but all you have to do is to get trained as a forklift operator, I do not know. A welder's training course is good too and this job will always be in really good conditions, no. [Beata, 30 years old]

Beata is not isolated in her views. Some of our interlocutors strongly believed that if you really wanted to work, you would find a job. This neoliberal worldview, which assumes that everyone is the architect of her own fate and the responsibility for failures is borne by an individual, presented by Beata and others, clashed with the interlocutors' conviction of how things ought to be (see White 2016) and with the fact that many people cannot find suitable vacancies. As Karol observed:

[my daughter-in-law] will not go abroad for sure, because she has a good profession. She is a dentist. But others who also have college degrees but majored in marketing or some such thing, do leave, because they can't find a job here [Karol, 60 years]. 


\section{SM̂PP}

Magdalena said something very similar:

What about you? Did you want to go abroad?

No. I have a good job here and I have a flat here. I don't need to go anywhere. I am satisfied with what I have. I would not want to leave. I visit my sister once a year and I also go on vacation, but that's enough. [Magdalena, 40 years old]

Mieczysław explained why nobody in his family went abroad:

Did anyone follow him [a brother who went to the USA]?

No, no. The brothers of my sister-in-law, they own private businesses and were not interested. One has a sawmill and the other owns a car mechanic workshop. And my sister is a dentist, she has never been interested in going abroad. So, from the family, apart from my brother, no one has gone anywhere. My children have good jobs, my son is a school teacher.

Here in Wronka?

Yes, in Wronka. Teaches PE in the primary school. My daughter is a secretary at the school. The second daughter-in-law works in the municipal office. And the second son works as machine operator in the city. He earns good money and is not interested in going anywhere. They have apartments here. [Mieczysław, 70 years old]

The interview quotes illustrate a certain pattern. If a person has a good job in town, there is no need to leave. People with good employment options include individuals working for the local government, in education, healthcare, as well as small business owners. We interviewed a local resident who became a producer of building insulation. He started his business after the Research Institute closed. Limited employment, however, is not able to meet the needs of all community members. Thus, migration plays the same role employment in the research institute and experimental plant played by providing a way to support one's family. People leave mainly to secure financial capital. Bartosz worked in Norway on a construction site to earn money to help his son with the mortgage. Zofia helped her son to buy a flat with money earned on a one-off contract in Norway. As Zofia said:

They have a flat without credit. That was the goal. Earn enough money to buy a flat and return. They have earned lots of money: one hundred fifty thousand zloty. We gave them the rest and bought a nice three-bedroom apartment. And they are happy, because other people here have twenty or thirty-year mortgages and they do not have any debt, no burden. [Zofia, 50 years old]

Sebastian mentioned that he bought a car with the money he earned abroad. Hanna organized a posh wedding for her daughter. Natalia goes to Spain every year to pick strawberries in order to save money. Marcin goes abroad to make money to pay off his house that he plans to sell with profit. Mariusz started to travel because 
the family needed money to care for a sick mother. Joanna's cousin brought her to England because her family's financial situation was very bad. Migration is often seen as an ad hoc solution conditioned by the existing economic situation. Halina said:

my husband had a job as a welder, but there was supposed to be better money abroad, better conditions and he wanted to earn some extra money. He thought he would put it down somewhere. But that was not possible. He came back and gave up altogether. He went back to his old job. [Halina, 45 years old]

It is worth emphasizing that the final outcomes of migration are affected by many factors, including the already mentioned social, educational, and economic capital, as well as migration circumstances. Mobility remains very individualized and, despite its universality, it is not a phenomenon that has been observed in social or institutional collective practices in the local community. It remains a private matter, a decision made at home, among relatives, without talking about it in the community. Our interlocutors experienced the bitterness of disappointments and sacrifices that migration brings. One woman mentioned her son's failure:

[He was on his own]. He had dreams, but he missed home and family too much. He dreamed of going to the States, because he has family there on his dad's side, he wanted to visit canyons. Maybe he will fulfil his dreams one day, but not yet. He was saving to go. [Jolanta 50 years old].

\section{Another respondent said bitterly:}

I think most, maybe 80 percent, have to leave. And those who return and say it was fun, they have to say it, because they just want to live there and are connected to life in England. When you meet your friend who has been in England for five years, he will not tell you that life in England sucks, right, especially if he wants to stay there. If his life is hard and his ass gets kicked at work, if the job pays badly, then he plans to go to another country or find another job, or he returns to Poland. [Łukasz, 40 years old]

Respondents acted upon the possibilities at their disposal. We have observed diverse forms of human agency, not limited to business practices, including the use of public benefits. Marlena described the experiences of her acquaintance:

She has been preparing to go abroad. She has already attended a job fair in Germany, in Munich, and made first contacts, but she cannot go yet, because she is still using different social benefits. She plans to import beautiful, wonderful costumes from Canada for fitness. And the second thing, she wants to get involved in real estate brokerage. She met a man who gives her cash to look for beautiful apartments. He pays her 500 euros, I think. Also, somehow, she is surviving although she doesn't have a job yet. [Marlena, 60 years old] 


\section{SM̂PP}

Our data show that mobility is a strategy to manage change. Wronka residents have made the best use of available resources: freedom to travel, EU citizenship, and independence from the state (see Garapich 2016: 38). Some people invested the money they earned. A niece of one of the interviewees bought two apartments at the seaside. She rents them to tourists, mainly from Germany, year-round. Respondents stressed that skills, including knowledge of foreign languages and experience gained abroad, are the undisputed value added of mobility. For example, the granddaughter of one of our respondents, whose daughter emigrated to the Czech Republic, became a translator. Employers look favourably on certain characteristics. "My father learned accuracy, punctuality, and work ethics in Norway," said Dawid. There are many things which people continuously bring to their communities of origin as a result of migration or circulation between destination and origin countries: gender equality, division of labour, individualistic lifestyles, new skills and sources of social capital, changing economic rationalities and emerging forms of collective action (Grabowska and Engbersen 2016: 112).

This does not mean that I want to promote an individual, active, and optimistic approach to social advancement and perception of mobility as a step up the social ladder. I also do not intend to share the uncritical optimism of the neoclassical migration theory, which glorifies return migrants as agents of change and innovation. Emigration for many of the study participants was a difficult, sometimes even traumatic, experience. It is important to note that current optimism regarding the development potential of migration also has a strong ideological dimension, as it fits very well into (neo) liberal political philosophies (see de Haas 2010).

\section{Emotional and social consequences of migration}

Empirical data confirm that the tendency of neoclassical migration theory to overemphasize individual achievements at the cost of analysing migrants within the context of social groups-such as households, families and communities-results in missing important parts of the holistic picture (see de Haas 2010). For our interlocutors who have experienced migration, it was very important to remain part of a social group, for emotional, social, and pragmatic reasons. Joanna complained that when she was abroad she missed out on many family celebrations. The cultural practice of attending weddings, funerals or christenings has major significance for many Poles (Grabowska and Engbersen 2016: 109). "More than simply continuing and recognising the religious and cultural traditions, mobility as an obligation acts as a motivation for the maintenance of social relations", observe some researchers (Ignatowicz 2011: 42). Joanna also emphasized the loneliness she experienced while abroad:

The worst thing for me was when my husband went to work. I was with the children all on my own. I had depression and doctors stuffed me with all sorts of medication. I had 
a terrible time. I have bad memories because I was on my own. For example, now when my husband is at work, I have my mother here, a friend or an aunt. I take the children and go out for coffee. I know, I'm out all day. And there, there were friends, but everyone had their own life, right? [Joanna, 40 years old]

\section{Beata concurred:}

We sometimes discuss this with friends when they come to visit. There is no family to help out. The state does not help out either. As you can see, here [in Wronka] there is always a mother or a grandmother to watch the children. There I always had to ask my neighbours: take my son for a moment, I need to hang up my laundry. It was like being in exile all the time. [Beata, approx. 30 years old]

Beata admitted that her husband's family returned to Poland because they could count on family members to help them out if need be. "Many people emigrate because they either don't have family or the family does not help them. And then what holds us here? And if you have someone who will help you out, then you want to come back, no?" - added Beata. But the issue is not just about pragmatism. As Ignatowicz assumes, migrants often rely on their networks at home for emotional and moral support (Ignatowicz 2011: 38).

Some respondents blamed migration for the destruction of family life. The main counter-argument to mobility and the reason for demonizing it was the breakup of families. Katarzyna said:

No, I know from experience that when they leave to go abroad, marriages break up and I have experienced it myself. My neighbour also has a second family. I hear about a lot of cases of marriage break-ups. I did not want to leave, he did not want to come back, and our marriage broke up.... So those who went with their family live best. [Katarzyna, 50 years old]

\section{Janusz concurred:}

Sometimes separation is great, right? (laughs). But not for long. And if you have young children, it's terrible. In our case, it works, but nevertheless we lose something. We are older, we can get over it, but it's more difficult for younger people. [Janusz, 60 years old]

These findings are reminiscent of White's research on labour markets, livelihood strategies, and migration patterns in small towns and rural areas, conducted in 2012-2013. White emphasizes the significance of family and friendship ties in influencing migration choices, which definitely did not seem to be made by individuals acting in isolation purely on the basis of economic rationality (White 2016).

Urszula's story points out another interesting issue. 


\section{SM̂PP}

My husband was in the United States, [he came back] he stopped giving me money. We had an agreement that I would use half of his Polish salary to support our two children and save the rest. We were to build a house. He had some troubles over there. At some point, he stopped writing and sending money. So, two options: either a woman or alcohol. Apparently, these are always the two options. Either he met a woman with whom he started a family or he drank so much that he did not have enough for a return ticket. He told me on the phone himself, which is rare, because it's alcoholism, it's a denial disease ...He just said: "Urszula, I drink". When he told me that, I said: "Come back, we love each other, I have your back no matter how much money you have. If you have enough for airfare, come back."

- Did he?

- Yes, but he was still an alcoholic and it was very hard and that's why I arranged my life differently. [Urszula, 60 years old]

Migration often means that family members, mostly women, become more independent and take over the responsibilities that had previously belonged to the migrating husband or wife (see Kurczewski and Fuszara 2012). Mobility contributes to the rise of new, more individualised lifestyles. These proliferate and have an impact on sending-community members (see Grabowska and Engbersen 2016).

\section{Maintaining long-distance relationships}

Migration forces individuals to maintain long-distance relationships. New technologies make it easier to stay in contact; Skype, Facetime, and WhatsApp have played an important role in the lives of our interlocutors. Contemporary forms of digital communication generate new transnational practices of caring for children (Grabowska and Engbersen 2016: 112). Izabella sang lullabies to her grandchild on Skype. She complained: "On Skype, I can neither touch nor hug my grandchild ... I can talk with my daughter, but she starts crying right away. Well, it was difficult for her. And for us, too." It is worth emphasizing that maintaining contacts with loved ones is a highly-individualized issue and depends on the type of relationship they have. A father of teenage children calls home twice a week; an adult son calls his parents once every two or three weeks:

because he "did not have anything to talk about", but another mother calls her daughter three or even four times a day. We have WhatsApp, we talk for hours, we send pictures, we exchange how-to ebooks. I'm on Facebook, so if I find something interesting or nice, I'll repost, my grandson too, so motivating ... Unbelievable, because I think we treat each other as friends, very deeply. She feels a bit lonely there, I understand her situation. [Urszula, 60 years old]

Our respondents included a lady who communicates more with her daughter in England than with her son in the next village. Another interlocutor confessed: "Well, 
some families are very close, they come every holiday. My sisters do not visit often. Now, the younger is planning to come in September, but will she really come?" Karolina shared an interesting story with us. Her daughter met her future Czech husband before the Internet era and waited for a letter from him:

Because we work here, we live in Wronka, but the letter went to Wörrstadt and then came back here. Well, it turned out that Edward still has to serve in the army for two years. She made herself a measure stick and marked every day. But in the meantime, the Velvet Revolution erupted. And then everything changed and he could come here. Even while in the army. And he came. And then this military service was shortened to 10 months, so he left the army and came here to us, and they decided that they were getting married. [Karolina, 60 years old]

Social media are not only new communication channels in migration networks, but they also actively transform the nature of these networks and thereby facilitate migration (see Dekker and Engbersen 2014). It is widely accepted that the nature of migration has been transformed by the facility for new technologies to enable migrants to maintain contacts with the society and community which they left. Migrants also learn specific transnational information practices through digital media. They not only communicate with members of sending communities by using active communication modes like Skype or email, but also passively monitor their activities by using social media. It allows them to maintain local identities and reduces isolation (Komito and Bates 2011). Specific transnational information practices through digital media may serve as a conveyor belt for the cultural diffusion of objects, ideas and practices (Bakewell et al. 2013, cited in Grabowska and Egbersen 2016: 109). Migrants often unintentionally create links between two societies. As Kennedy assumes, the consequences of networks forged by migrants can enhance cosmopolitan understanding and deepen globality (Kennedy 2010: 92).

\section{Mobility and meeting "others"}

Migrants of many different regional, ethnic and national origins forge transnational networks across the world. Networks including representatives of many ethnic and cultural groups spread in many directions and connect very different societies together through the many flows and links of socio-cultural activity. Most societies now contain a number of socio-cultural enclaves which have been transplanted and reconstructed within their borders by a variety of migrant groups (Kennedy 2010: 92). Even migrants from small Polish towns and villages to small towns and villages in the UK (see White $2011 \mathrm{~b}$ ) get the experience of cultural diversity from rich contacts with receiving societies and adopt some values and practices.

Interestingly, except for one sailor who expressed racist views, we have not encountered any manifestations of xenophobia in Wronka. Although the Polish public 


\section{SM̂PP}

debate does not condone the use of the term "ciapaty" to describe a Muslim or more broadly a foreigner, some of our interlocutors defended the use of the word claiming that there is no negative emotional charge behind its use:

I went to the pizzeria just before it closed. There was a woman there, Shala, very nice. Ciapata, that's what they call them. She made me a nice pizza from the leftovers. All my family members were awaiting the pizza. [Joanna, 30 years old]

Kamil described his point of view as follows:

I met a guy once. He was different, dark, a Muslim, a Pakistani. I met all sorts of different [people], had the opportunity to get to know different cultures. Everybody is nice once you get to know them. [Kamil, 40 years old]

Interlocutors used the term "refugee", but without a clear understanding of its definition:

I will tell you honestly that when I was in Germany, only modest people live in the city centre, either refugees or from abroad, hardly anyone lives in the centre of the city. I have a friend again, she lives $30 \mathrm{~km}$ from Hamburg in the countryside, but it turns out that there are artists, singers, painters, gay people... There are beautiful houses there. It's a paradise, people flee from big cities, they do not want to live in the centre. [Urszula, 50 years old].

On the other hand, the interviews with Wronka inhabitants leave no doubt as to how strong their Polish national identity is. As Kennedy argues, it is easier for economic migrants today to retain or even enhance their sense of nationalism when living abroad because in general host cultures are now much more tolerant of ethnic diversity, dual identities and the retention of some aspects of home culture than was the case a hundred years ago (Kennedy 2010: 91). Migrants from Poland have a range of options to keep in contact with their homeland by, among others mentioned above, maintaining relationships and media, especially through the internet ${ }^{10}$. Migrants' social and economic lives are not bounded by national borders (Pessar 1999, cited in Levitt 2001: 5).

Respondents experienced new things when they went abroad. Some things surprised them; the legality of drinking beer at a railway station in the Czech Republic, the Dutchmen's and Norwegians' attitude to their living quarters. "They do not pay as much attention to their place of residence as we do. We have to build a house but they are satisfied with 60 square meters", said Marek. Polish migrants also do not mind a mass with dancing and singing for Jamaican migrants, for example. People are confronted with a dominant set of values, norms, and behaviours which are

10 And the internet, quite the opposite to the conviction that it is global and international, as a matter of fact redounds to proliferation of national rhetoric (see Pobłocki 2001). 
frequently assumed through the production of national ideologies, history textbooks, state orchestrated rituals, symbols, and everyday actions. On the other hand, migrants are continually required to adapt these norms and values to the new circumstances in which they find themselves - in a process involving individual choices, modes of behaviour, strategies of interaction, and creation of meaning.

\section{Conclusions}

Polish migration within Europe has increased since Poland's accession to the EU, but Poles were migrating even before 1989. This paper analysed mobility and migration in the context of larger social and political processes, including the process of political transformation that took place in Poland after 1989. On the basis of data obtained during fieldwork, I conclude that mobility was practised before 1989, but after the fall of socialism mobility has become the norm in the community previously centred around the state farm.

Migration (including local migration) influences this local community first of all in a demographic sense. New inhabitants replace those who moved out. The redevelopment of a former hotel into apartments was not without significance. It is obvious that new settlers were attracted by the short commuting distance from the city. However, if Wronka does not continue enjoying a good reputation that was shaped in the years of the Institute' functioning, the town will depopulate like many similar provincial towns. The emergence of new settlers makes the old Wronka community more upset than the outflow of its inhabitants. Mobility is perceived in the community as a necessity which emerges mostly for economic reasons. It explains why the migration of relatives remains a private issue embedded in informal networks. The question of migration stays inconspicuous also because visible investments undertaken by return migrants do not occur in Wronka. Most of the inhabitants treat the migration abroad as a temporary strategy to improve their livelihoods. After their return they look for jobs in nearby cities.

This article is a case study of a small town in West Pomerania and it presents the residents' narratives of mobility. Wronka residents have used mobility as a strategy to cope with social and economic changes and to improve their livelihoods. Both of these strategies are perceived as acts of individual agency (see Grabowska 2016). In addition to showing the economic causes and effects of mobility, I have also focused on its unintended consequences, including the attainment of social capital, the ability to adapt to norms and values and to particular circumstances, and new practices and systems developed during migration. Looking at Wronka from an historical perspective (the town was established shortly after WWII) and its special genesis (the local community was created from the employees of the Research Institute and the Experimental Plant) allows us to see connections between specific aspects 


\section{SM̂PP}

of the local community's life and local and global processes, including those that originated in the past.

I strongly believe that a methodological and empirical focus on local communities in the context of mobility can enhance Polish migration studies, especially the perception that migration projects are part of other processes, deeply embedded in social, cultural, and historical experience. This perspective enables scholars to appreciate migrants who leave to improve their livelihoods regardless of the outcomes. An appreciation of the value of social remittances - new skills and knowledge - can weaken negative attitudes towards migrants and transnational families instead of seeing them as a problem, as was the case with the media-created moral panic about the so-called "Euro-orphans" (Main and Czerniejewska 2017: 12; 2016: 31-32).

Polish education and prevailing public discourse depict Polish history strictly within the borders of a nation-state. There is a need to underscore the role of migration and mobility in the history of Poland. The reasons for going places result mainly from economic circumstances, and the practices of mobility have been formed by migrants' social backgrounds. Similarly, the desire to stay in the country is most often determined by the need to remain within the smallest social group, i.e. the family.

\section{References}

Baba, M. L., Dahl-Jørgensen C. (2010). Work Migration from Poland to Norway: A New Institutional Approach. iNtergraph: Journal of Dialogic Anthropology 2 (2) (Re-issue), http:// intergraph-journal.net/enhanced/vol2issue2/2.html.

Bakewell O., Engbersen G., Horst C., Fonseca L. (eds) (2016). Beyond Networks. Feedback in International Migration. Basingstoke, London: Macmillan Palgrave

Basch, L., Glick-Schiller, N. Szanton Blanc, C. (1994) Nations Unbound: Transnational Projects, Postcolonial Predicaments, and Deterritorialized Nation-States. Basel, Switzerland: Gordon and Breach.

Black, R., Engbersen G., Okólski M., Pantîru C. (Eds.) (2010). A Continent Moving West? EU Enlargement and Labour Migration from Central and Eastern Europe. Amsterdam: University Press.

Brettell, C. B. (2000.) Theorizing Migration in Anthropology: The Social Construction of Networks, Identities, Communities, and Globalscapes. In Migration Theory, ed. C.B. Brettell and J.F. Hollifield. New York: Routledge, pp. 97-136.

Buchowski, M. (2008) Widmo orientalizmu w Europie. Od egzotycznego Innego do napiętnowanego swojego. Recykling Idei 10: Imperium (przesytka zwrotna): 98-107.

Buchowski, M. (2017). Czyściec. Antropologia neoliberalnego postsocjalizmu. Poznań: Wydawnictwo Naukowe UAM.

Czapiewska, G. (2003). Historyczne uwarunkowania rozwoju rolnictwa uspołecznionego na Pomorzu Środkowym. Słupskie Prace Geograficzne 1: 51-67.

Dekker R., Engbersen G. (2014). How Social Media Transform Migrant Networks and Facilitate Migration. Global Networks 14(4): 401-418.

Elrick T. (2008). The Influence of Migration on Origin Communities: Insights from Polish Migrations to the West. Europe-Asia Studies 60(9): 1503-1517. 
Garapich, M. (2016). London's Polish Borders. Transnationalizing Class and Ethnicity Among Polish Migrants in London. Ibidem Verlag.

Goździak, E., Pawlak M. (2016). Theorizing Polish Migration Across Europe: Perspectives, Concepts, and Methodologies. Sprawy Narodowościowe Seria nowa 48: 106-127.

Grabowska, I. (2016). Movers and Stayers: Social Mobility, Migration and Skills. Frankfurt am Main: Peter Lang Verlag.

Grabowska, I., Engbersen G. (2016). Social Remittances and the Impact of Temporary Migration on an EU Sending Country: The Case of Poland. Central and Eastern European Migration Review 5 (2): 99-117.

Grabowska, I., Garapich M., Jaźwińska E., Radziwinowiczówna A. (2017). Migrants as Agents of Change. Social Remittances in an Enlarged European Union. Palgrave Macmillan UK.

Grabowska I., Sarnowska J. (2017). Transnarodowe wielostanowiskowe jakościowe badanie powtórzone w migrujących społecznościach lokalnych. Przegląd Socjologii Jakościowej, 13(3): $6-28$.

Grabowska-Lusińska, I., Okólski M. (2009). Emigracja ostatnia? Warszawa: Wydawnictwo Naukowe Scholar.

de Haas, H. (2010). Migration and development: a theoretical perspective. International Migration Review 44 (1): 227-265.

Ignatowicz A. (2011). Travelling Home: Personal Mobility and 'New' Polish Migrants in England. Studia Migracyjne - Przegląd Polonijny 37(1): 33-47.

Jaźwińska, E., Grabowska I. (2017). Efekty społecznych przekazów migracyjnych (social remittances) w polskich społecznościach lokalnych. Studia Socjologiczne, 1: 139-165.

Kaczmarek, P., Tyrowicz J. (2015). Winners and Losers among Skilled Migrants: The Case of PostAccession Polish Migrants to the UK. IZA Discussion Paper. Institute for the Study of Labor 9057, May.

Kennedy P. (2010). Local Lives and Global Transformations: Towards World Society. Basingstoke: Palgrave.

Kocik L. (2001). Trauma i eurosceptycyzm polskiej wsi. Kraków: Drukarnia Narodowa S.A.

Komito L., Bates J. (2011). Migrants' Information Practices and Use of Social Media in Ireland: Networks and Community. http://www.ucd.ie//komito/iConference2011-komito.pdf (accessed 14 February 2019).

Kurczewski J., Fuszara M. (2012). Modernizacja czy kryzys? Przemiany rodzin czasowych migrantów. Societas/Communitas 13: 79-108.

Levitt, P. (1998.) Social Remittances: Migration Driven Local-Level Forms of Cultural Diffusion. International Migration Review 32(4): 926-948.

Levitt, P. (2001). The Transnational Villagers. University of California Press.

Main, I., Czerniejewska, I. (2017). Post-accession Female Mobility between Poland and Norway. New Trends and New Ways of Thinking about Migration. Sprawy Narodowościowe. Seria Nowa 49. https://doi.org/10.11649/sn.1358.

Marcus G., E. (1995). Ethnography in/of the World System: The Emergence of Multi-Sited Ethnography. Annual Review of Anthropology 24: 95-117.

Okólski, M. (2001). Mobilność przestrzenna z perspektywy koncepcji migracji niepełnej. In: Ludzie na huśtawce. Migracje między peryferiami Polski i Zachodu, ed. E. Jaźwińska, M. Okólski, Warszawa: Scholar, 31-61. 
Okólski, M. (2012). Spatial Mobility from the Perspective of the Incomplete Migration Concept. Central and Eastern European Migration Review, 1 (1): 11-36.

Orozco, M. (2013). Migrant Remittances and Development in the Global Economy. Boulder: Lynne Rienner Publishers.

Pobłocki, K. (2001). Online National Communities. Polish Sociological Review, (134), 221-246. Retrieved from http://www.jstor.org/stable/41274800.

Pobłocki, K. (2010). The Cunning of Class: Urbanisation of Inequality in post-war Poland. Unpublished PhD thesis. Budapest: Central European University.

Sala, J., Tańska, H. (2016). Competences in the knowledge-based economy. Position Papers of the Federated Conference on Computer Science and Information Systems 9: 219-224.

Slany, K. (ed.) (2008). Migracje Kobiet. Perspektywa wielowymiarowa. Kraków: Wydawnictwo Uniwersytetu Jagiellońskiego.

Sztompka, P. (2000). Trauma wielkiej zmiany. Warszawa: Instytut Nauk Politycznych.

White, A. (2010). Family Migration from Small-Town Poland: A Livelihood Strategy Approach. In Polish Migration to the UK in the "New" European Union: After 2004, ed. Kathy Burrell. Burlington: Ashgate, 67-86.

White A. (2011a). Polish Families and Migration Since EU Accession. Bristol: The Policy Press.

White A. (2011b). The Mobility of Polish Families in the West of England: Translocalism and Attitudes to Return. Studia Migracyjne - Przegląd Polonijny 37(1): 11-32.

White, A. (2016). Informal Practices, Unemployment, and Migration in Small-Town Poland. East European Politics and Societies: and Cultures 30 (2): 404-422.

Wimmer A., Glick Schiller N. (2002.) Methodological nationalism and beyond: nation-state building, migration and the social sciences. Global Networks 2 (4): 301-334.

Winiecki, J. 2001. Historia polskiego marginesu. Online: http://archiwum.rp.pl/artykul/367122_Historia_polskiego_marginesu.html (accessed: 21 January 2018). 